\title{
EVALUATING GRAMMATICAL COMPETENCE IN KURDISH EFL JUNIOR STUDENTS' WRITINGS AT THE ENGLISH DEPARTMENT, COLLEGE OF LANGUAGES, UNIVERSITY OF DUHOK
}

\author{
Mohammed Salih A. Sulaiman and Hajin GHaZi Mohammed \\ Dept. of English, College of Language, University of Duhok, Kurdistan Region-Iraq
}

(Received: May 27, 2019; Accepted for Publication: July10, 2019)

\begin{abstract}
While writing is as important as the other three skills (reading, listening, and speaking), most students have a big problem with it. This could be the fault of the teaching methods/techniques or the materials used in classrooms. This paper aims at evaluating the grammatical competence in Kurdish EFL students' writings. The aim is to point out those areas of grammar that need more focus and determine which teaching techniques and materials are most suitable for helping students in developing their writing skills. The researcher first evaluated students' grammatical competence using a test, and then evaluated their ability to apply grammatical rules in their written essays. The data from the grammar test and the essay test were analyzed using the SPSS (Statistical Package for the Social Sciences) Software. The participants were 93 students at the English Department of Duhok University. The results indicated that the students had struggled most with prepositions in the grammar exam and had the least trouble with pronouns. However, regarding the essay test, majority of the students made errors concerning articles, and the least number of errors were made regarding coordinators. It was, however, found that the students avoided the use of complex grammatical structures in their writings, and it could be because there is not enough practice in the classroom.
\end{abstract}

KEY WORDS: Grammatical Competence, Grammar, Writing, Teaching Techniques, EFL Students

\section{INTRODUCTION}

I $t$ is believed that writing is one of the main pillars of language learning, and therefore, should be of major concern and interest to teachers, students, and researchers. Grammar is the structure, sound, and meaning system of language (Hajana, 2006). All languages have grammar, and people who speak the same language can communicate because they instinctively know the grammar system of that language (Hajana, 2006). According to Hinkel (2013), different second language skills and language features have different levels of importance in academic writing. In ESL education, the study on recognizing simple and complex grammatical constructions and vocabulary has been encouraged by the goal of aiding students to improve and develop the quality and sophistication of their production and writing in a second language. The next few sections will discuss the significance of writing, the significance of grammar in developing writing skills, grammatical competence, research hypothesis, research aims, and structure of the study.

\subsection{The Significance of Writing Skills}

Of all the language skills, the most challenging for language teachers is writing because students do not have much experience with written expression. Ariana (2010) stated that because students are stimulated by audiovisual materials all through their lives, they are beginners when it comes to writing. Ariana (2010) believed that when writing is continuously taught in a foreign language acquisition class from the first day, it will help ensure students' success. According to Ariana (2010), writing skills help learners become independent, understandable, fluent and creative in writing, and it also helps them form their thoughts meaningfully on paper and grasp the message in an appropriate manner. Ariana (2010) claimed that whether a person is a businessperson, an English teacher, or a student, (academic) writing skills are essential in the world today because all kinds of papers, such as: essays, presentations, research papers, reports, 
etc., must be written in the correct style. Usually, institutions have tried to deal with nonnative speakers' writing needs differently from native speakers', as it used to be possible to let nonnative students graduate without expecting them to write as well as native English speakers, however, today they are required to write with the same proficiency as native speakers. It is, therefore, suggested by Ariana (2010) that writing activities should be designed in ways which help students learn how to create cohesive and coherent discourse in order to become improved writers and better critics of their own writings. It is also suggested that the initial focus of writing practice must not be on the accurate word or phrase only, but on the whole communication process which helps develop the quality and image of the learner himself/herself (Ariana, 2010).

\subsection{The Significance of Grammar in Developing Writing Skills}

Hinkel (2013) conducted a research on the significance of Grammar in developing Writing Skills. He pointed out that teaching grammar is important for producing second language academic and formal prose. In his research, Hinkel (2013) focused on certain grammar constructions, such as (sentence construction, verbs and the verb phrase, noun clauses in restatement and for paraphrasing, nouns, noun phrases, and pronouns, adverb clauses and adverbs, exemplification markers, etc) and their associated lexical elements which are important in teaching second language academic writing. According to Hinkel (2013), these necessary elements of academic grammar skills are required for students who seek success in their university work. Hinkel (2013) also believed that conversational fluency does not bring with it the skills which are needed for producing academic text. Taking English as an example, Chin (2000) stated that students who are native speakers of English recognize the sounds of the English words and they know the different ways of putting those words together in order to make meaningful sentences. However, even though students may be good speakers of English, they need assistance in becoming good writers as well by learning to transfer the grammatical concepts that they know from oral language to written language. Chin (2000) believed that by connecting the oral language that they know to written language, teachers can clarify the abstract terminology of grammar so that students can write and read more competently and confidently. Effective grammar instruction starts with what students know about grammar already, and it helps them in using this knowledge when they write. Research strongly suggests that the best way to help students improve their knowledge of grammar in writing is to utilize the students' writing as the basis for the discussion of grammatical concepts (Chin, 2000).

A study was conducted by Jones, Myhill, and Bailey in 2012, and according to them, the role of grammar teaching in the teaching of writing is argued about in most English-speaking countries, with several strong analyses not finding any evidence of beneficial effect. In their study, Jones, Myhill and Bailey (2012), set out to examine the influence of contextualized grammar instruction on the writing performance of students. Jones, Myhill and Bailey's (2012) research implemented an approach with mixed methods along with a randomized controlled trial as well as a complementary qualitative study and the results indicated that there was a positive effect on the writing performance of able writers more than weaker writers.

Another study was conducted in 2016 by Robinson and Feng in order to investigate the effects of direct grammar teaching on the quality of the writing skills of the students. Robinson and Feng (2016) stated that grammar teaching has an important role to play in aiding students in speaking and writing more effectively. Based on the results of the pre-assessment writing scores of the students, through Write Score (which is a company that offers hand scored essays and open-response questions with human graders), direct grammar teaching was administered to tackle the common errors that were found in their writing (Robinson \& Feng, 2016). The results showed that after four months of being taught direct grammar, half of the students who partook in the study showed a large increase in their overall writing scores, and those students were able to make sufficient progress to enhance their writing when grammar instruction was employed during writing instruction (Robinson \& Feng, 2016). Robinson and Feng (2016) believed that teachers should get more training in order to increase their knowledge of useful research-based writing approaches to improve their students' overall 
writing quality. They pointed out that writing is a complex task for many students and that is why quality teaching is needed on a daily basis.

Zina (2015) believed that grammar is a major area of writing and it is regarded as one of the most necessary elements for good writing. The main goals of Zina's (2015) paper were to draw teachers' and learners' attitudes towards the method which is actually used in teaching grammar and to shed light on the possible relationship between integrative grammar teaching and developing learners' writing. Another goal of Zina's (2015) paper was to determine to which extent integrative grammar can improve academic writing. Zina (2015) suggested some recommendations, such as grammar teaching as related to the text types which are required to be learnt in order to improve learners' writing at the Department of English. After analyzing the findings acquired from the teachers' and students' questionnaires, results showed that students make a lot of errors in their writing and most of them do not make a balance between form and content (Zina, 2015). Additionally, the experiment outcomes showed a positive relationship between the dependent and independent variables and the development of experimental group after the treatment stage which means that students can decrease the number of errors they make in their writing and they can also create a balance between form and content at the same time through integrative grammar instruction (Zina, 2015). According to Zina's (2015) findings, teachers believed that integrative grammar instruction is beneficial and will ease their work in teaching writing and students believed that integrative grammar is expected to develop their writing. This expectation was proved through testing the efficiency of integrative grammar instruction with second year students in which it showed a development at the grammar level, which therefore, lead to increase in writing (Zina, 2015).

\subsection{Grammatical Competence}

The term "grammatical competence" was introduced by Chomsky, which he defined as "the speaker-hearer's knowledge of his language" (Chomsky, 1965, p.4). According to Yule (2010: p.194), grammatical competence involves the correct use of words and structures. Tanaka (n.d. p.51) believed that grammatical competence is undoubtedly the most important part of communicative competence. Tanaka (n.d. p.51) stated that those who have good grammatical competence must; (1) be conscious of the basic rules of English, for instance, word order, agreement in number and verb conjugation; (2) be capable of constructing a series of chunks for the purpose of communication; (3) be sensitive to the interrelatedness of various functions of a single form; (4) retain a stock of constructions of conventional chunks which are related to ideas, such as negation, comparison, and modality; (5) be capable of observing and judging whether or not a given grammatical deviation is acceptable in a natural discourse, and also (6) be able to self-edit their English as needed. According to Millrood (2014: p.260), grammatical competence can be seen as a set of rules and language skills which are needed for learners; (1) to create correct sentences, (2) to understand them, (3) to check grammatical errors, (4) to judge correct and incorrect linguistic forms, and (5) to do language testing tasks.

\subsection{Research Hypothesis}

The teaching techniques used by a teacher influence the performance of students, and therefore, a teacher must be careful in selecting the techniques they wish to follow. The present study hypothesizes the following:

1- With the techniques used in teaching, in the English Department at College of Languages, the focus is more on learning grammar rules rather than being competent in using these rules in writing.

2- Students avoid using complex grammatical constructions in their writings for fear of making grammatical errors. Consequently, students cannot develop the ability to write well-formed pieces of writings in English.

In order for these hypotheses to be viewed as valid or invalid, an experiment was conducted by first testing students' grammatical competence and then collecting essays written by college juniors from the English Department to check their grammatical performance in writing after three years of college training. If the aforementioned hypotheses are proven to be correct, the techniques for teaching, used in the English Department at the College of Languages, should probably be changed or improved. 


\subsection{Research Aims}

This study aims at suggesting different teaching techniques for developing students' grammatical competence in writing by evaluating Kurdish EFL students' level of grammatical competence in writing. The main goal here is to determine what areas of grammar need more focus so as to help students develop their writing skills regarding the students who participated in the experiment. An EFL teacher's main goal is to develop their students' language skills: listening, speaking, reading, and writing. With the help of this research, the teachers at the mentioned college will be able to see how much of the language their students have grasped, what areas in grammar they excel in, and in what areas they need improvement in order to help them develop in writing. With this perception of students' grammatical competence, these teachers can change or develop their teaching techniques, should they need to. This research attempts to aid teachers in creating a syllabus which is beneficial to their students as well as helps them choose the appropriate materials and resources in their curriculum. This research also attempts to help the students to be aware of their grammatical weaknesses in writing so that they could choose the most suitable learning strategies for themselves in their learning process.

\subsection{The Structure of the Study}

This study is made up of five sectionss. Section One consists of the significance of writing skills, the significance of grammar in developing writing skills, grammatical competence, research hypothesis, research aims, and the structure of the study. Section Two explains the methodology adopted in this study (the participants and the tools) as well as data collection process. Procedures and data analysis are also discussed in this section. In Section Three, the results of the study are discussed. Section Four offers a discussion of the findings and some pedagogical implications from the researcher. Section Five sums up the thesis with conclusions taken from the results.

\section{METHODOLOGY}

A quantitative approach alone was used to accomplish the experiment in this research because only tests and essays were used to assess students' grammatical competence in writing; thus, only requiring an analysis of data and numbers, neither interviews nor questionnaires were used. As writing is one of the important skills in mastering a language, students must be competent enough in that aspect of language because, in addition to its significance in education, writing is used as one of the main means of communication today. This study was designed to evaluate the grammatical competence of students in the English Department at the College of Languages in Duhok University.

\subsection{Participants}

The students who partook in this study were junior students at the English Department of the College of Languages at University of Duhok, which was where the study took place. The University of Duhok is located in the city of Duhok, which is a city in Kurdistan region of Iraq. The test was administered in a classroom at the English Department. The reason that only junior students were chosen for this research was because the researcher wanted to choose students who had taken Grammar and Writing for at least three years. It was also believed that since the participants were taking Academic Writing, they were more familiar with writing than freshmen and sophomores. And since seniors did not have a subject on writing, they were not suitable for this experiment because authentic essays, written by students, were required. All three junior groups were selected for this research and there were ninety-three students in all, twenty-eight students were from group A, thirty-one were from group B, and thirty-four were from group C. The sampling strategy used is known as "purposive sampling", which according to Cohen, Manion, and Morrison (2007), refers to choosing participants because they meet particular criteria which you are seeking for your study. The researcher believed that whether the students were male or female will not have an effect on the results, the experiment had a mixture of both, and therefore, were all treated equally gender-wise. It would have been fascinating to examine the results based on gender as well; nevertheless, that was not the case for this study, as it was not of importance to the researcher. The participants of this research had studied (3) hours of grammar and (2) hours of writing a week for the duration of their junior year, and they had also studied grammar their freshman and sophomore years. 


\subsection{Tools}

The tools required for this study were a paper and pencil test and essays written by students. For the first part of the study, students took a grammar test on paper and handed them to the researcher when they had completed it. The aim of this test was to evaluate the students' grammatical competence and it contained ten questions, each covering one aspect of grammar, such as: tenses, pronouns, prepositions, coordinators, concord, comparative and superlative forms, quantifiers, gerund and infinitives, articles, and modals. The questions were in the form of either a multiple-choice question, fill-in-the-blank question, asking students to change the verb form, or asking them to change the adjective form. For the second part, the students wrote a short essay for the final exam as required by their Academic Writing teacher. The topic of the essay is whether or not success is related to money. There is no fixed length for the essay. These essays were collected and corrected to evaluate the students' ability to apply grammatical rules in their writings. The reason behind collecting essays written by students in their final exam, was to investigate whether or not students are able to accurately apply the grammar rules they learned in Grammar in writing.

\subsection{Data Collection}

This study employed a quantitative approach in analyzing its data. The data which was collected for this study was results from a grammar test taken by each third-year student at the end of the academic year (2018) and an essay which each one of them had written for their Academic Writing final exam. This data was then taken to be corrected by the researcher and inputted in the computer which was later analyzed using the SPSS software. First the researcher marked all of the students' tests and essays and then recorded the correct and incorrect answers from the test as well as the grammatical errors made by students in their essays. This recorded data was then inputted into the computer. The SPSS software analyzed all data. A descriptive analysis was used. Through the SPSS software, the researcher found the means value of the correct answers for each question in the grammar test as well as the average mean for the overall question. Similarly, using the SPSS software, the researcher was able to calculate the number of students who had applied certain grammar items correctly in their written essays, the number of students who had applied certain grammar items incorrectly in their written essays, and the means value of the accurate use of a particular grammar item. The test contained ten questions covering the most important aspects of grammar which, according to research on the topic, (Fareed, Ashraf, \& Bilal (2016), Ho and Duong (2015), and Roshni (2017)) considered most relevant to academic writing. These features had been studied by students during the past three years, and they include tenses, pronouns, prepositions, coordinators, concord, comparative and superlative forms, quantifiers, gerund and infinitives, articles, and modals. In order to verify the validity of the test questions, the researcher consulted three content experts. A pilot study was not carried out for this research as the researcher got the test questions from online English tests and an experienced lecturer at the English Department at the College of Languages at University of Duhok who had used them many times to test his students' competence in grammar. Also, the common errors found in studies by Fareed, Ashraf, and Bilal (2016), Ho and Duong (2015), Pesce (n.d.), and Roshni (2017) are tenses, articles, subjectverb agreement, prepositions, incorrect use of word classes, singular and plural, sentence structure, the use of informal and spoken language, word forms, verb forms, collocations, spelling, punctuation, gerund and to-infinitive, misuse of adverbs and adjectives, degrees of adjectives, omission of words, and word order, which seem like the most difficult grammatical items for any ESL learner. Therefore, the questions which were used to evaluate students' grammatical competence were believed to be reliable, as they covered most of the aforementioned grammar items. This does not mean, however, that the other items are not relevant in writing. The students did not have any difficulty with understanding the questions as they were familiar with such tests regarding the form of the questions and the terms used. In the test, students were required to fill in the blanks, choose an answer from multiple choices and accurately change the form of words. Each group of students were tested separately, nevertheless, all in one day.

\subsection{Procedures and Data Analysis}

The researcher first chose all junior students from the English Department at the College of Languages at University of Duhok for the experiment and evaluated their grammatical 
competence using a test. This test was taken at the end of the academic year because the researcher thought it best to give the students the chance to finish their course in Grammar and Academic Writing. Then the researcher collected the tests on the same day that the students had taken them and took them to correct. The correction process lasted for three days, the researcher spent one day correcting each group's tests and there were three groups participating in the study. The students were also each asked to write an essay for their Academic Writing class in the final exam which the researcher collected afterwards. The topic of the essay was the same for all of the students. The researcher corrected students' essays. When correcting the essays, the researcher took into consideration all of the ten grammatical items used in the test, as well as any other grammatical item which may have surfaced. The correction process lasted for three consecutive days. Because the students' written essays may not have contained all the important aspects of grammar to be analyzed, a test focusing on those aspects was also given to students to take. This was to evaluate students' grammatical competence and see whether or not they are able to successfully apply what they know about grammar in their writing. The researcher entered the students correct and incorrect answers into the computer by numbering them from (S1-S93). The researcher named each blank by its order in a question, for example "blank 1" was given the code (B1) and so on. The SPSS software was used to analyze the recorded data in order to find out the students' areas of strength and areas of weakness in grammar. Finally, the researcher compared the results of the tests and the results of the essays to see whether students only understand grammar rules, or they are also able to successfully apply these rules in writing as well. Using the SPSS software, we calculated the percentage of the most and least errors made by students, in the grammar test and their essays. The researcher inserted the students' correct and incorrect answers of the grammar test and the grammatical errors which they had made in their written essays into the SPSS software. Afterwards, the SPSS software calculated the mean of the correct answers in the grammar test as well as the mean of the students who had applied grammatical items accurately in the essay test, the sum of the students with the correct answers in the grammar test along with the sum of the students who had used certain grammatical items correctly and incorrectly in the essay test, and the standard deviation. These calculations were then displayed in numerous tables. However, only the mean value of the correct answers is of importance to this study as the purpose is to evaluate the grammatical errors made in the grammar test and the essay test so as to find out the students' areas of strength and weakness.

\section{RESULTS AND FINDINGS}

The data showed that students had the most difficulty with prepositions in the grammar exam and the least difficulty with pronouns. On the other hand, the majority of students made errors concerning articles, in their essays, and the least number of errors were made regarding coordinators. The results of the grammar test show that only (.19\%) of students answered questions regarding prepositions accurately; however, $(.70 \%)$ of students answered questions regarding pronouns correctly. A percentage of just $(.32 \%)$ students applied articles correctly, in their essays; yet, $(.95 \%)$ of students managed to use coordinators accurately. Nonetheless, there were other grammatical items with which students had a great deal of trouble. Tables 1 and 2, below, will be discussed.

$(B=$ blank, $N=$ number of students, Sum = sum of students with correct answers $)$ 
Table (1):Question 1 (Tenses) in grammar written test

\begin{tabular}{lr|r|r|r|r|r|r|r|r|r|r|r}
\hline & B1 & B2 & B3 & B4 & B5 & B6 & B7 & B8 & B9 & B10 & B11 \\
\hline & & & & & & & & & & \\
\hline N Valid & 93 & 93 & 93 & 93 & 93 & 93 & 93 & 93 & 93 & 93 & 93 \\
\hline \multicolumn{1}{c}{ Missing } & 0 & 0 & 0 & 0 & 0 & 0 & 0 & 0 & 0 & 0 & 0 \\
\hline Mean & .67 & .0 & .6 & .1 & .2 & .4 & .2 & .0 & .0 & .10 & .35 \\
& & 6 & 2 & 1 & 6 & 8 & 9 & 0 & 4 & & \\
\hline Sum & 62 & 6 & 58 & 10 & 24 & 45 & 27 & 0 & 4 & 9 & 33 \\
\hline $\begin{array}{l}\text { Average } \\
\text { Mean }\end{array}$ & .27 & & & & & & & & & & \\
\hline
\end{tabular}

Table (2): Students' Written

\begin{tabular}{|c|c|c|c|}
\hline & \multicolumn{3}{|c|}{ Essays } \\
\hline N=93 & $\begin{array}{c}\text { Correct } \\
\text { Sum }\end{array}$ & $\begin{array}{c}\text { Incorrect } \\
\text { Sum }\end{array}$ & Mean \\
\hline Tenses & 49 & 44 & .53 \\
\hline Pronouns & 69 & 24 & .74 \\
\hline Prepositions & 53 & 40 & .57 \\
\hline Coordinators & 88 & 5 & .95 \\
\hline Concord & 34 & 59 & .37 \\
\hline Degrees of Adjectives & 38 & 55 & .41 \\
\hline Quantifiers & 85 & 8 & .91 \\
\hline Gerund/To-Infinitive & 63 & 30 & .68 \\
\hline Articles & 30 & 63 & .32 \\
\hline Modals & 81 & 12 & .87 \\
\hline Singular/Plural & 49 & 44 & .53 \\
\hline Auxiliaries & 54 & 39 & .58 \\
\hline Word Order & 82 & 11 & .88 \\
\hline Valid N (listwise) & & & \\
\hline & & & \\
\hline
\end{tabular}

According to Table 1 and Table 2, more students had used tenses correctly in their essays than in the grammar test. However, it does not necessarily mean that they are not aware of the grammatical rules of tenses but are able to apply them properly in actual writing. The data revealed that they try to avoid using complex tenses in their writings and only use simple tenses, such as: simple present, simple past, and simple future, as opposed to the grammar test in which only four blanks were either simple present, simple past, or simple future tense. It was found from the data that, in their essays, very few students had used complex tenses combined with progressive and perfective aspects (present perfect, past perfect, present perfect continuous and past continuous, which suggests that they were afraid of using complex 
tenses so as to avoid making errors. It is important to mention that among the 93 students, $(.47 \%)$ of them did not use tenses correctly, which indicates that almost half of the students are not competent in applying tenses correctly in writing. Students were limited to using one or two tenses throughout their essays, and this could be the result of the way in which they were taught essay writing. Teachers of writing tell their students to use the same tense all through their essays because going back and forth in terms of tenses is not permitted in writing. While this can be true, students misconstrue this statement and stick to exactly one tense alone. It does not, however, seem plausible to use one single tense throughout an entire piece of writing. When the simple present tense is used in any writing, the present perfect, the present continuous, or the simple past will bound to be used as well.

Question 2 (Pronouns) in grammar

Table (3): written test

\begin{tabular}{|c|c|c|c|c|c|c|}
\hline & & B1 & B2 & B3 & B4 & B5 \\
\hline$N$ & Valid & 93 & 93 & 93 & 93 & 93 \\
\hline & Missing & 0 & 0 & 0 & 0 & 0 \\
\hline \multicolumn{2}{|c|}{ Mean } & .85 & .56 & .86 & .84 & .42 \\
\hline \multicolumn{2}{|c|}{ Sum } & 79 & 52 & 80 & 78 & 39 \\
\hline \multicolumn{2}{|c|}{ Average } & .70 & & & & \\
\hline \multicolumn{2}{|c|}{ Mean } & & & & & \\
\hline
\end{tabular}

Table 3 and Table 2 show that students did not have much difficulty with pronouns in both the grammar test $(.70 \%)$ and the essay test (.74\%). Though an extremely small number of students answered questions in the grammar test related to pronouns inaccurately and applied them incorrectly in the essay test or did not apply them at all, the researcher suggests that teachers provide more in-class activities which will enhance the students' performance in using pronouns, because the data proposes that only personal and reflexive pronouns were used accurately by the students in the grammar test and only personal pronouns and the relative pronoun who were used accurately in the essay test. This shows that students are not creative when it comes to using pronouns in writing, either because they are not aware of all of them or because they do not know how they are applied in writing. 
Journal of University of

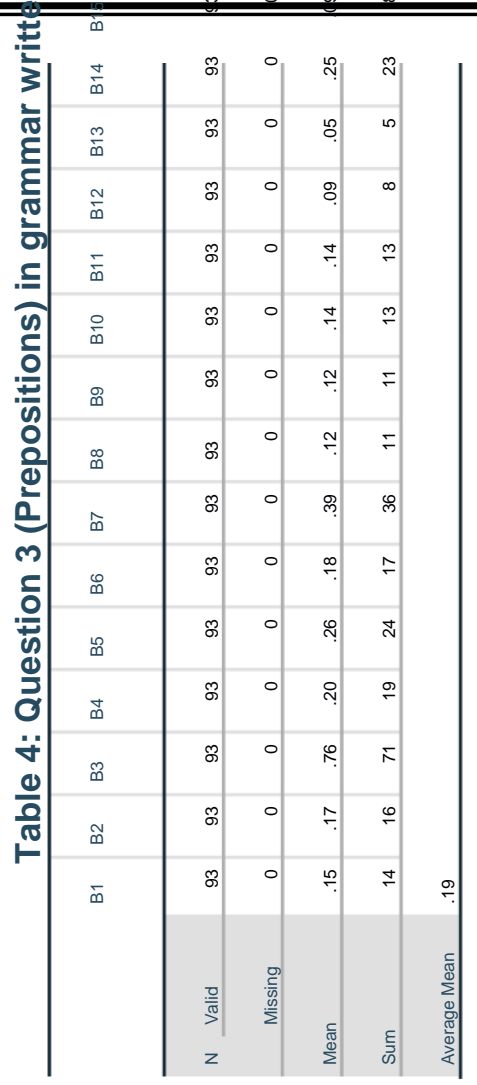

While pronouns are not a weakness for the students, the same cannot be said about prepositions. In Table 4 and Table 2, it is shown that, in the grammar test, very few students answered the question regarding prepositions accurately and only a few students were able to apply prepositions appropriately in their essays, $(.19 \% 0$ and $(.57 \%)$ respectively. The data concluded that students were extremely incompetent when it came to preposition of direction as no

\begin{tabular}{|c|c|c|c|c|c|c|c|}
\hline & \multicolumn{7}{|c|}{$\begin{array}{c}\text { Table (5): Question } 4 \text { (Coordinators) in grammar written } \\
\text { test }\end{array}$} \\
\hline & B1 & B2 & B3 & B4 & B5 & B6 & B7 \\
\hline $\mathrm{N}$ Valid & 93 & 93 & 93 & 93 & 93 & 93 & 93 \\
\hline Missing & 0 & 0 & 0 & 0 & 0 & 0 & 0 \\
\hline Mean & .51 & .37 & .15 & .30 & .10 & .09 & .19 \\
\hline Sum & 47 & 34 & 14 & 28 & 9 & 8 & 18 \\
\hline $\begin{array}{l}\text { Average } \\
\text { Mean }\end{array}$ & & & & .24 & & & \\
\hline
\end{tabular}

answered it correctly in the grammar test and only two students used them in their essays. This leads the researcher to believe that, when learning an aspect of grammar such as prepositions, students should be given opportunities to practice all of its types so as to be aware of their use in actual writing. 
The data in Tables 2 and 5 indicate that students performed poorly in the grammar test with regard to coordination, with a percentage of (.24\%); yet had performed extremely well in the essay test, with a percentage of $(.95 \%)$. However, like the previously mentioned grammatical items, students were very limited in the use of coordinators in their essays, in that most of them had used and, but, and/or because, while other coordinators, such as: or and yet, either...or and neither...nor had hardly been used or not been used at all.

Table( 6): Question 5 (Concord) in

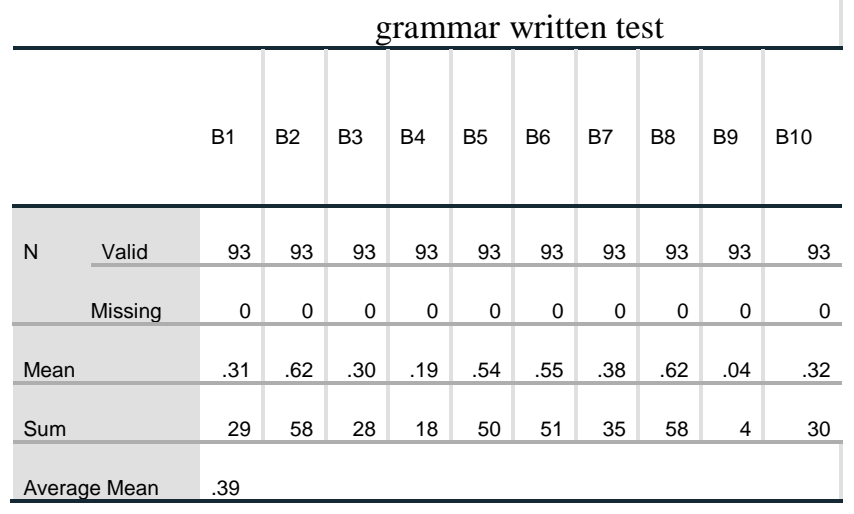

Similarly, when it comes to concord, students were equally weak in its use, in both the grammar test and the essay test. The data in Tables 2 and 6 suggest that, overall, students had trouble with concord in both the grammar test and the essay test. In the essay test, only (.39\%) of students answered the questions accurately and in the essay test, (.37\%) of students applied them correctly in their essays. The only subjectverb agreement in which many of the students did not have difficulty with, in neither the grammar test nor the essay test, was that of collective nouns.

Table (7): Students' results for

Question 6 (Degrees of

Comparison) in grammar written

\begin{tabular}{|c|c|c|c|c|c|c|c|}
\hline & & B1 & B2 & B3 & B4 & B5 & B6 \\
\hline \multirow[t]{2}{*}{$N$} & Valid & 93 & 93 & 93 & 93 & 93 & 93 \\
\hline & Missing & 0 & 0 & 0 & 0 & 0 & 0 \\
\hline \multicolumn{2}{|c|}{ Mean } & .70 & .05 & .82 & .42 & .83 & .25 \\
\hline \multicolumn{2}{|c|}{ Sum } & 65 & 5 & 76 & 39 & 77 & 23 \\
\hline \multicolumn{2}{|c|}{ Average } & .51 & & & & & \\
\hline
\end{tabular}

Also, the students performed poorly in the grammar test as well as the essay test with regards to degrees of adjectives. The data in Table 7 and Table 2 show that more than half of the students were incapable of applying comparative and superlative adjectives and adjectives to the same degree correctly in both the grammar test and their essays. Albeit, students were the most competent in use of comparative adjectives; however, they were least competent in the use of adjectives to the same degree. On the other hand, there were many 
students who completely avoided the use of comparatives and superlatives in their essays. Like other aspects of grammar, if degrees of adjectives are not used properly in writing, it makes the writing seem unnatural. Therefore, EFL students must practice using these degrees of adjectives in writing to avoid having their writings be considered unusual.

Table (8): Question 7 (Quantifiers) in grammar written test

\begin{tabular}{lll|l|l|l|l}
\hline & & B1 & B2 & B3 & B4 & B5 \\
\hline $\mathrm{N}$ & Valid & 93 & 93 & 93 & 93 & 93 \\
\cline { 2 - 7 } & Missing & 0 & 0 & 0 & 0 & 0 \\
\hline Mean & .22 & .83 & .31 & .46 & .33 \\
\hline Sum & 20 & 77 & 29 & 43 & 31 \\
\hline Average Mean & .43 & & & & \\
\hline
\end{tabular}

The data in Table 8 further suggests that $(.57 \%)$ of the students had trouble with quantifiers in the grammar test. Nearly half of them had used some, many, and a lot correctly in their essays. There were, however, very few students who had applied much correctly in their essays and only one student who had applied little correctly in. There were even few students who had used much where a lot was supposed to be. quantifiers can be confusing to EFL learners and therefore, they must practice using them as often as possible in order not to mix them up in writing.

Table (9): Question 8 (Gerund/To-Infinitive) in grammar written test

\begin{tabular}{|c|c|c|c|c|c|c|c|c|}
\hline & & B1 & B2 & B3 & B4 & B5 & B6 & B7 \\
\hline \multirow[t]{2}{*}{$N$} & Valid & 93 & 93 & 93 & 93 & 93 & 93 & 93 \\
\hline & Missing & 0 & 0 & 0 & 0 & 0 & 0 & 0 \\
\hline \multicolumn{2}{|c|}{ Mean } & .81 & .67 & .30 & .44 & .60 & .60 & .63 \\
\hline \multicolumn{2}{|c|}{ Sum } & 75 & 62 & 28 & 41 & 56 & 56 & 59 \\
\hline \multicolumn{9}{|c|}{ Average Mean .57} \\
\hline
\end{tabular}

Regarding gerund and to-infinitive, more than half of the students performed well in both the grammar test and the essay test. According to the data of the grammar test, more errors were made concerning to-infinitive than gerund. On the other hand, the data in of the essay test show that more errors were made concerning gerund than to-infinitive. Yet, the difference in the number of errors between gerund and toinfinitive, in both tests, was close to nothing, and therefore, it can be concluded that the junior students are neither weaker nor stronger in using either 


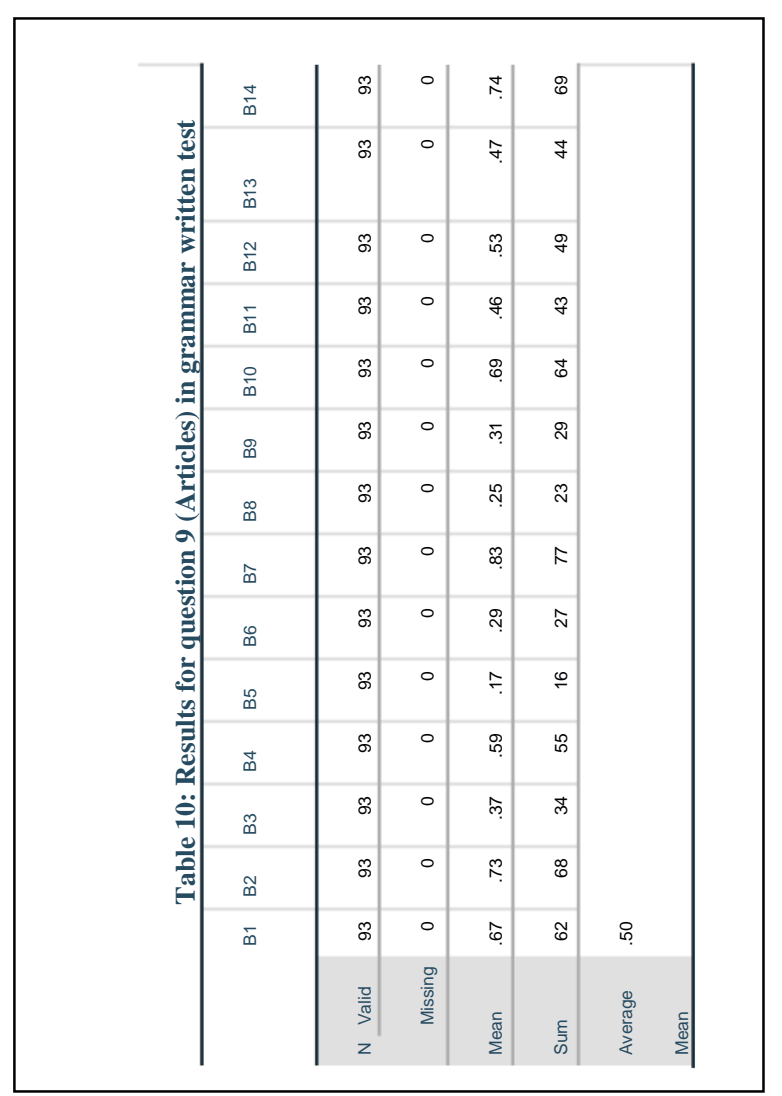

When it comes to using articles, students had more difficulty with the definite article the and the zero article $\varnothing$ than the indefinite articles $a$, $a n$ in the grammar test and in their essays. Similar results were also found in a study conducted by Miller in (2005) who suggested that ESL learners find the definite article and the zero article more difficult than the indefinite articles because they are not as restricted in their use as indefinite articles are, which can cause confusion.

Table 11: Question 10 (Modals) in grammar written

\begin{tabular}{|c|c|c|c|c|c|c|}
\hline & & B1 & B2 & B3 & B4 & B5 \\
\hline \multirow[t]{2}{*}{$N$} & Valid & 93 & 93 & 93 & 93 & 93 \\
\hline & Missing & 0 & 0 & 0 & 0 & 0 \\
\hline \multicolumn{2}{|c|}{ Mean } & .33 & .47 & .48 & .61 & .34 \\
\hline \multicolumn{2}{|c|}{ Std. Deviation } & .474 & .502 & .502 & .490 & .478 \\
\hline \multicolumn{2}{|c|}{ Sum } & 31 & 44 & 45 & 57 & 32 \\
\hline \multicolumn{2}{|c|}{ Average Mean } & .44 & & & & \\
\hline
\end{tabular}

Concerning modals, students performed better in the essay test than in the grammar test, $(.87 \%)$ and $(.44 \%)$ respectively; however, in the essay test, only can, should, 
and will were used by most of the students. The other modals were completely neglected by almost all of the students. There is a correlation between the students' performance in the grammar test and their performance in the essay test, in that; in the essay writing, they avoided those grammatical items which they had not answered correctly in the grammar test.

There were grammatical errors found in the students' essays other than those present in the grammar test. According to the data in Table 2, $(.53 \%)$ of the students knew when to make nouns singular or plural; yet, the rest of them did not. Similarly, as Table 2 suggests, $(.58 \%)$ of students used auxiliaries correctly, and the remaining applied them incorrectly, whether it was in the incorrect form or the incorrect auxiliary entirely. Table 2 also shows that word order was another error found in the essays. However, only $(.12 \%)$ of the students mixed up the order of the words in their essays, whereas the others did not seem to have any trouble in that area.

\section{DISCUSSION}

The findings suggested that students are aware of the simple present, simple past, and simple future; yet, only a small number of them had managed to use present perfect and present continuous in writing. Also, passive voice and past participle were used incorrectly by almost all of the students. Future perfect continuous, on the other hand, was not used by a single student in the essay test and was not answered accurately by any of the students in the grammar test. Most of the students who answered questions related to pronouns accurately in the grammar test, only answered the ones regarding personal and reflexive pronouns correctly, and only applied personal pronouns and the relative pronoun Who correctly in the essay test. From the findings, it could also be concluded that students are, to a degree, aware of prepositions of place, time and agent prepositions; yet, they are unaware of preposition of direction, because not a single student answered them accurately in the grammar test, and only two students applied them in the essay test. Moreover, while students are capable of using some coordinators, such as: and, but and/or because, they are incapable of using coordinators, such as or and yet. Students' overall performance of concord was weak. Apart from concord of collective nouns, almost all of them had difficulty with concord, especially concord of compound nouns. Regarding degrees of adjectives, most of the students performed well with respect to comparative adjectives in the grammar test; however, they had trouble with superlative adjectives and adjectives to the same degree. Yet, in the essay test, less than half of the students were capable of applying degrees of adjectives accurately, the rest did not use any form of comparative/superlative adjectives. Only two students used adjectives to the same degree in their essay. Similarly, students performed poorly, in the grammar test, regarding quantifiers; yet, performed well in the application of them in the essay test; however, majority of the students used the quantifiers some, many, and a lot, and only very few of them applied other quantifiers. There were some students who used much instead of a lot and vice versa. In the grammar test, more errors were made regarding to-infinitive than gerund; though, in the essay test, more errors were made with respect to gerund than to-infinitive. Therefore, it is appropriate to conclude that students are neither stronger nor weaker when it comes to gerund or to-infinitive. In both the grammar test and the essay test, concerning articles, students had the most difficulty with the zero article and the least difficulty with the indefinite article. Also, most students applied the definite article where the zero article was supposed to be and vice versa. Regarding modals, students' overall performance was weak in the 
grammar test, and though the results indicated that students had performed well in the essay test, regarding modals, very few of them were capable of using modals other than can, should, and will in their essay. There were also other errors that were found in the essay test which were not present in the grammar test, such as singular and plural nouns and auxiliaries, which barley half of the students had applied accurately in their essays. Word order was another error found in the students' essay; however, only few students made errors in that regard.

Similar errors were found in a study done by Fareed, Ashraf, and Bilal (2016). The highest number of errors found in Fareed, Ashraf, and Bilal's (2016) research was made in grammar. The grammatical errors included incorrect use of word classes, prepositions, articles, tenses, subject-verb agreement, singular and plural nouns, verbs, sentence structure, as well as the use of informal and spoken language (Fareed, Ashraf, and Bilal, 2016). In another study conducted by Ho and Duong (2015), it was discovered that the most frequent errors found were tenses, word forms, verb forms, collocations, prepositions, spelling, subjectverb agreement, articles, and adjective \& noun order. Similarly, in an article by Roshni (2017), it was found that the most common errors that students in India make, in writing, are incorrect use of verb forms, incorrect use of subject-verb agreement, not using commas with coordinators, not using punctuation and spelling correctly, and misplacing words, especially modifiers. In a website called Busy Teacher, an article was written by Pesce (n.d.), who had stated that many students make errors regarding, tenses, prepositions, gerund and to-infinitive, articles, misuse of adverbs and adjectives, subject-verb agreement, singular and plural nouns, degrees of adjectives, omission of words, and word order. The common errors found in all of these studies, including this research, are tenses, articles, subject-verb agreement, and prepositions, which seem like the most difficult grammatical items for any ESL learner. This does not mean; however, that the other items are not relevant in writing. It can be concluded that students stay away from using complex grammatical items in their compositions for fear of making errors, which is why the results of their essays were better than the results of their grammar test. Therefore, it can be said that the earlier made hypothesis has been verified, as the students avoid using complex sentence structures which proves that there is a lack of practice in using these constructions.

Nevertheless, it is important to point out that, although some grammatical items were not used in the essays by the students, it is not sufficient to state that they are incompetent in using them in writing because no one can apply all the grammar items in one piece of writing. Therefore, future researchers can collect several essays written by each student so as to come to a better conclusion. What does affect the quality of a student's essay, however, is when students use a grammatical feature incorrectly or apply one grammatical feature where another is supposed to be used, which was found a great deal, in this study.

\subsection{Pedagogical Implications}

The researcher believes that teachers can teach students to plan what they want to write before they write. After that the teachers can teach students about revising and rewriting their first draft so as to help them improve their writing. There are three popular approaches, among others, to writing which the researcher believes can be helpful in the instruction of writing, and they are known as "The Product Approach", "The Process Approach", and "The Genre Approach". According to Tudor (2016: p.3), the product approach refers to valuing model texts, which means that students first read a model text and then they do exercises which concentrates on the language which was used in the model text, such as the present perfect, and try to produce writing with similar language. In the product approach, the focus is on the accuracy of grammar. Tudor (2016) defined the 
process approach as referring to planning and drafting before writing. The genre approach means providing students with genre knowledge (Tudor, 2016). This means that if teachers want their students to write a business letter, then they would first give the students some business letters to read so that they know how a business letter is written and what kind of language is used in a business letter. Tudor (2016) believed that using any of these three approaches alone is insufficient for the production of a good writing. Therefore, Tudor (2016: p.3) suggested another approach known as "The Process Genre Approach", which combines the key elements of all three approaches. This approach was introduced by Badger and White 2000 (cited in Tudor, 2016: p.3). According to Tudor (2016), the aforementioned approach first puts the students' focus on a situation taking place for which a text is needed. The students will identify why they will produce a text, to whom they will produce a text, what they will produce in a text, and how they will produce a text (Tudor, 2016). Students are led through key processes, as well as planning and drafting and peer input is believed to be of value at these stages for allowing opportunity to share schemata (Tudor, 2016). Furthermore, model texts that have the same genre can be presented to help the students investigate the genre (Tudor, 2016). According to Tudor (2016), students may bounce between these stages, as necessary, when preparing for a final draft; also, an important feature which the process genre approach possesses is that it does not follow inflexible, linear stages. There are other techniques which teachers can follow in order to help their students develop their writing. The researcher suggests that teachers try and help their students understand that, in writing, while it is important to remain consistent in using a tense, changes should be made when appropriate. For example, when there is a time shift in their writing, then it would be appropriate to change the tense according to what timeframe they are describing in their writing, otherwise, they should stick to the tense they began with. This will make students' writings contain a more natural flow. Teachers should also try to give their students more reading practices, when students read articles, books, etc., they will be able to see and understand how certain grammatical items are used in writing; hence, their writing will improve. Using materials, such as: newspapers, articles, a few pages from a book, short texts, etc., is crucial in writing instruction because students need to observe closely how different grammatical features are used in different genres. Also, when choosing a topic for their students to write, teachers should choose topics which are realistic and relatable for students so that they can be motivated to write. Teachers can do as the teachers at the American University of Kurdistan do and have students submit a weekly essay. The teacher can give students a different topic each week with a different genre. However, before assigning students the task of writing an essay, teachers should teach their students English collocations and chunks related to that genre. For instance, if the teacher asks the students to write an invitation letter, they could first teach students phrases, such as: "I would like to invite you to....", "would you consider coming to...?", "I would really appreciate it if you came to....", and so on. This way, students would learn English in chunks as well as collocations and punctuation, which will aid them, later on, in their writing of the letter, essay, etc. with fewer grammatical errors. One of the main issues with ESL/EFL students' writings is that, when they write, they do not think in English, they think in their native language and translate it into English; therefore, many of their sentence patterns are incorrect because of transference from their native language. To avoid this, the researcher recommends teachers to encourage their students to read a lot so as to be exposed to authentic English. Reading in English will help students be familiar with English expressions which they can use later on in their writing. In addition to reading a lot in English, listening to native speakers speak in English as well as communicating in English will facilitate the students' ability to think in English. Thinking in English while writing, makes the students' writing seem more natural, as opposed to thinking in their native language and translating it into English. The researcher believes that helping students learn to think in English is extremely crucial in any EFL classroom because not only does it develop the students' writing ability, but it enhances the fluency in their speech as well. Writing classes should integrate grammar instruction within the teaching of 
writing without making it a grammar lesson, so as to help students be more aware of the application of grammatical features in writing, and avoid making grammatical errors as much as possible.

Below is a text sample, emphasizing tenses, retrieved from Lynch and Anderson (2013: p.54):

During the cold war, Britain occupied a pivotal position in education and politics because it had collaborated with Bulgarian officials in placing UK teachers of English in English language medium schools throughout Bulgaria. After the dismantling of the former Eastern bloc, the UK (primarily through the British Council) continued to place the majority of its teachers in English language medium schools throughout Bulgaria. The British expanded their role in English language education to include teacher education and consultancy. In this way, they preserved their influence as curators of the institution of the English language - a valued linguistic currency both during and after the cold war.

Using the text sample above, teachers can explain to students when to use the simple past tense and when to use the past perfect. For example, after having presented a text containing the simple past and past perfect to students, teachers can describe to them that action which contains had before it, such as (had collaborated) in the text, means that it has occurred before the action which only has an -ed attached to it, such as the word (occupied) in the text. Afterwards, the teacher could give students some exercises to do in class to practice the simple past tense and the past perfect in order to be more familiar with their application in writing. Also, through a text similar to the following sample text, articles can be taught to students:

I work part-time in a student counselling centre in Athens, where I have been a volunteer for the past three years. The centre has team of six staff, each of whom has their own consultation room. But most of my time I spend studying for my $\mathrm{PhD}$ in the Department of Psychology, which is on the main university campus. The Department is in two sections: the main building is in very poor condition but the annexe is much more modern. I share a workroom in the annexe with four other students, which is not very convenient.

Retrieved from Lynch and Anderson (2013: p.14)

Using this type of text, a teacher can explain to their students how articles are applied in writing correctly. For example, the teacher could clarify to students how when first introducing a noun, the indefinite article $a$ should be used, such as in the underlined part of the text $a$ student counselling centre; however, when the same noun is mentioned a second time, the definite article the should be used, such as in the phrase the centre, in the second sentence of the text. The teacher should explain that this is because it is assumed that the reader already knows what the writer is referring to. The teacher could also explain to their students that the zero article is used before certain nouns, such as the proper noun, Athens, in the text. The teacher can provide activities where students can practice these articles and, later on, apply them in their own writing. Correspondingly, punctuation can also be taught along with other grammatical features through texts. Likewise, after explaining certain grammatical items in a grammar lesson, teachers should teach their students how those grammatical items are used in writing as well, and give students many opportunities to practice those grammatical items in writing. The grammar lesson should depend on the students' areas of weakness, and therefore, it is crucial that teachers be aware of what their students need more practice in so as to base their classroom activities and lesson on it. Because the aim of this research is to evaluate the students' grammatical competence in writing, it is the researchers hope that instructors of English find the results of this study helpful and useful in their instruction.

\section{5-CONCLUSION}

Although many students are competent in skills, such as: listening, speaking, and reading, they have difficulty with writing. They tend to misuse tenses and articles and they have trouble linking ideas together. Unfortunately, some teachers do not realize this issue with their students, nor do they feel they are responsible for addressing it. The present study has arrived at the following concluding remarks:

1-The students had struggled most with prepositions in the grammar exam and had the least trouble with pronouns.

2-Majority of the students made errors concerning articles, in their essays, and the least number of errors were made regarding coordinators.

3-The researcher concluded that there was a link between the students' performance in the grammar test and their performance in the essay test, as in the essay writing, they avoided the grammatical features which they had not answered correctly in the grammar test.

4-At the beginning of this study, the researcher hypothesized that the teaching techniques used in the English Department at College of Languages at University of Duhok put more focus on learning grammar rules than being competent in using those rules in writing, and 
therefore, learners cannot develop the ability to write well-formed pieces of writings in English. After conducting an experiment and carefully analyzing the data, it was found that while students performed better in the essay test than in the grammar test, it does not necessarily suggest that they are capable of writing wellformed writings, because the researcher found that, in their essays, students only used those grammar items which they had answered correctly in the grammar test and avoided those items which they had answered incorrectly in the grammar test.

\section{REFERENCES}

Ariana, S. 2010. Some Thoughts on Writing Skills. Annals of Faculty of Economics, 1(1), 127-133.

http://citeseerx.ist.psu.edu/viewdoc/download?doi=10 .1.1.838.6129\&rep=rep1\&type $=$ pdf

Chin, B. (2000). The Role of Grammar in Improving Student's Writing. Sadlier-Oxford. Retrieved from

http://people.uwplatt.edu/ ciesield/graminwrit ing.htm\#About\%20the\%20Author

Cohen, L., Manion, L., \& Morrison, K. (2007). Research Methods in Education. (6th ed.). Abingdon. Routledge.

Davis, W. (1996). Educational Implications of a Study on Grammar and Basic Writing Skills in a Developmental English Course. Eric, Retrieved from https://files.eric.ed.gov/fulltext/ED392067.pdf

Fareed, M., Ashraf, A., \& Bilal, M. (2016). ESL Learners' Writing Skills: Problems, Factors and Suggestions. Journal of Education and Social Sciences, 4(2), 81-92.

Hajana, O. (2006). The Relationship between Grammatical Competence and Writing Quality (Master's Thesis, University of Khartoum, Khartoum, Sudan). Retrieved from http://khartoumspace.uofk.edu/bitstream/handl e/123456789/11117/The\%20Relationship\%20 Between\%20Grammatical.pdf?sequence $=1$

Hinkel, E. (2013). Research Findings on Teaching Grammar for Academic Writing. English Teaching, 68(4), 3-21.

Ho, P., \& Duong, P. (2015). Common Errors in Writing Journals of the English Major Students at HCMC Open University. Journal of Science Ho Chi Minh City Open University 2(14), 52-61.

Jones, S., Myhill, D., \& Bailey, T. (2012). Grammar for Writing? An Investigation of the Effects of
Contextualized Grammar Teaching on Students' Writing. Reading and Writing, 26(8). http://dx.doi.org/10.1007/s11145-0129416-1)

Lynch, T \& Anderson, K. (2013). Grammar for Academic Writing. English Language Teaching Centre, Edinburg, FUniversity of Edinburgh.

Miller, J. (2005). Most of ESL Students Have Trouble with the Articles. International Education Journal 5(5), 80-88.

Pesce, C. (n.d). 10 Biggest ESL Grammar Mistakes and How to Keep Your Students from Making Them. Retrieved from https://busyteacher.org/18253-10-biggest-eslgrammar-mistakes-students-make.html

Richard, J. \& Rodgers, T. (2001). Approaches and Methods in Language Teaching ( $2^{\text {nd }}$ ed.). Cambridge: Cambridge University Press.

Robinson, L., \& Feng, J. (2016). Effect of Direct Grammar Instruction on Student Writing Skills. Paper Presented at Eastern Educational Research Association Annual Conference, Hilton Head Island, South Carolina. Retrieved from https://files.eric.ed.gov/fulltext/ED564336.pdf Roshni. (2017). 9 Common Grammar Mistakes that Make Students Lose Marks. Retrieved from https://www.indiatoday.in/educationtoday/grammar-vocabulary/story/commongrammar-writing-mistakes-962657-2017-0225

Thornbury, S. (1999). How to Teach Grammar. Harlow. Pearson Education Limited.

Tudor, E. (2016). The Process Genre Approach in Writing: An Alternative Option for the Modern Classroom. https://files.eric.ed.gov/fulltext/ED571522.pdf

Wei, M. (2017). Strategies for First-Year University ESL Students to Improve Essay Writing Skills. (Master's thesis, University of San Francisco, San Francisco, California). Retrieved from https://repository.usfca.edu/capstone/536

Zina, Z. (2015). The Role of Integrative Grammar in Developing Academic Writing: Case Study Second Year Students of English at Biskra University. (Master's thesis, University of Biskra, Biskra, Algeria). Retrieved from http://dspace.univbiskra.dz:8080/xmlui/bitstream/handle/123456 789/6030/zarfaoui\%20zina.pdf?sequence $=1 \& \mathrm{i}$ sAllowed $=y$ 


\section{Appendices}

Appendix 1 Test Questions

Q.1 Fill in the blanks with the correct form of the given verbs.

1. By the time 1 got to the office, the meeting (begin, already).

2. We (wait) for the bus for nearly half an hour, but it (not arrive) yet so I don't think we (be able to) attend the meeting on time.

3. When Sarah (study) English for nearly four years.

4. Right now Susan is in the hospital. She (graduate) from university next year, she and arm.

5. She (always want) to be an actress but she (treat) for a bad burn on her hand alternative careers.

\section{Q. 2 Choose the appropriate options to complete the sentences.}

1. We all told the boss that we wanted to have salaries paid in advance but he just ignored

\footnotetext{
A) ours / it

B) his / we

C) their / our

D) we / his

E) our / us
}

2. Although in the room seemed to follow said by the speaker, he never intended to simplify his language.
A) no one / anything
B) anybody / anything
C) nobody / nothing
D) anyone / nothing
E) someone / something

3. I hope you will enjoy at the re-union party this weekend because I won't be able to be there
A) you / myself
B) yourself / mine
C) yours / oneself
D) yourself / myself
E) you / me

4. Thousands of children nowadays prefer doing to doing in a quiet room.
A) theirs / them
B) is / its
C) them / it's 
D) they / them

E) their / it

5. Trademarks enable a company to distinguish products from of another company.
A) their / it
B) it / that
C) our / this
D) its / those
E) my / these

\section{Q3. Fill in the spaces with appropriate prepositions.}

\section{A.}

1. We are going

2. There is a bridge holiday next week.

3. He screamed the river.

4. A small stream runs me angrily.

5. Did you vote that bridge.

B. the suggestion?

Late one evening __ our way home _ the studio, we pulled up _ a red light. As we chatted quietly _ the day's work, something suddenly kicked us _ the rear and my feet went _ _ my head. I reached out __ Steve, screaming. I didn't know where down was, and my head wouldn't move my neck. The car came __ a halt. We had been knocked sixty feet __ the opposite side of the highway the path of oncoming traffic.

\section{Q 4. Complete the paragraph using the correct coordinators.}

Fans love to watch Anna, she dances beautifully. She performs with a fan, people enjoy watching her. She hasn't taken dance lessons, does she need to. Her technique is unconventional, the effect is striking. She can fill an audience with joy, she can bring people to tears. Other dancers try to imitate her style, fans for many years to come. they have not succeeded. She is talented, she will attract

\section{Q 5. Fill in the blanks with the correct form of the verb in brackets.}

1. playing sports such as tennis and basketball but also physical strength. (require, requires) not only mental ability

2. Everyone

3. Half of the class

4. Neither the teacher nor the students

5. Each of the cars in the street

6. The staff (was, were) shocked by the news of their boss.

7. Every man and woman

8. None of them (have, has) shoes to wear.

(have, has) problems.

9. Bread and butter (is, are) our daily food.

10. Twelve miles (is, are) a long distance to run.

\section{Q 6. Fill in the blanks using the appropriate adjective.}


1. My sister thinks she's (intelligent) than me, but I don't agree!

2. My house is almost (big) yours!

3. Do you think the Harry Potter films are (good) than the books?

4. Who is (powerful) person in your country?

5. Is Angelina Jolie (old) than Sandra Bullock?

6. John is (nice) person that I know.

Q 7. Complete the sentences using one of the following words: much, many, some, few, a few, little, a little.

students were able to pass the exam. It was rather disappointing. We need to teach them better, and fast because we don't have time left. Ryan is among the students who had failed, he had so needs on his mind that he couldn't concentrate on the exam. I think he just counselling from his teachers. push in the right direction, he'll be fine. He may also need

\section{Q 8. Complete the paragraph using the appropriate gerund or infinitive.}

We are sitting in a restaurant and we have asked the waiter (bring) the menu, though I'm thinking about (ask) for a cup of tea only because I'm so sad, I miss (be) with you so much. I hope (be) strong enough (resist) tomorrow's excursion. We will probably start (drive) towards old eastern Germany early in the morning, since they say there are a couple of extraordinary things (see) somewhere called Leipzig.

\section{Q 9. Complete the letter using the correct article (a, an, the, Ø).}

Dear Judy,

Sorry that I didn't email you earlier to tell you about trip. We had fantastic time in South Africa. We began _ trip in _ Cape Town as you suggested. While we were taking in spectacular views, we met __ man who runs __ lodge just outside __ Kalahari National Park. We rented __ car and slowly drove up Kalahari Desert. What adventure! West Coast to park and spent our time exploring

\section{Q 10. Fill in the blanks with the appropriate modals.}

1. It isn't cold outside. You (mustn't, needn't, shouldn't, can't) wear a coat.

2. I can hear footsteps in the flat upstairs, so there (must, can, may, should) be someone there.

3. My letter (must have arrived, may arrive, can't have arrived, should have arrived) yesterday, but it didn't

4. I'm not sure, but I (should have seen, may have seen, can see, must have seen) Sue in town last night. Judging by the state of the children's bedroom, there has to be) a riot in it. (might have been, may be, might be, 


\section{Appendix 2 Essay Sample}

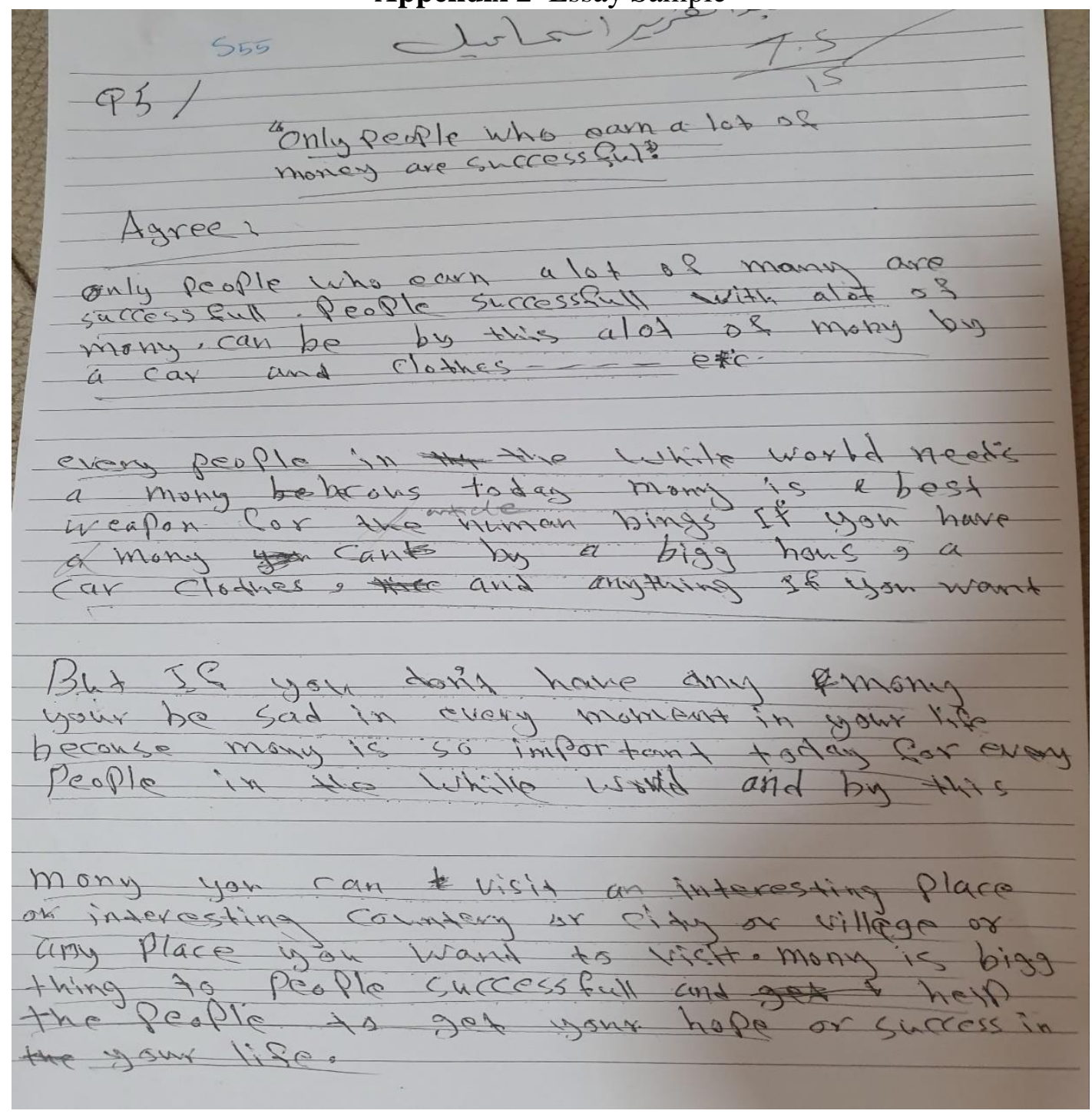

